Article

\title{
Electric Trolley Trucks-A Techno-Economic Assessment for Germany
}

\author{
Martin Wietschel ${ }^{1,2}$, Till Gnann ${ }^{1, *} \mathbb{C}$, Patrick Plötz ${ }^{1}\left(\mathbb{D}\right.$ and Claus Doll ${ }^{1}$ \\ 1 Fraunhofer Institute for Systems and Innovation Research ISI, Breslauer Str. 48, 76139 Karlsruhe, Germany; \\ martin.wietschel@isi.fraunhofer.de (M.W.); patrick.ploetz@isi.fraunhofer.de (P.P.); \\ claus.doll@isi.fraunhofer.de (C.D.) \\ 2 Institute for Industrial Production (IIP) at the Karlsruhe Institute of Technology (KIT), Hertzstrasse 16, \\ 76187 Karlsruhe, Germany \\ * Correspondence: till.gnann@isi.fraunhofer.de
}

Received: 10 September 2019; Accepted: 25 November 2019; Published: 29 November 2019

check for updates

\begin{abstract}
Road freight transport is responsible for about one-third of road transport emissions and it is still growing. One solution to decarbonize this sector are electric trolley trucks powered by overhead lines. We compare electric trolley trucks to conventional diesel vehicles from a techno-economic perspective in Germany up to 2030. We find that an infrastructure set-up ordered by utilization of roads can be financed up to $2700 \mathrm{~km}$ with higher savings than cost. The impact on the energy system is lower than expected and the largest impacts are found in rural areas with highway intersections. Further fields of research are discussed.
\end{abstract}

Keywords: road freight transport; overhead lines; electric trolley truck; infrastructure build-up; electric truck

\section{Motivation}

A recent study of the International Energy Agency [1] shows that trucks will surpass passenger cars as the major oil consumer in the next decades. Furthermore, trucks will be responsible for $15 \%$ of the increase in global $\mathrm{CO}_{2}$ emissions. Also in Germany, trucks are currently responsible for more than $20 \%$ of the transport sector's total greenhouse gas (GHG) emissions [2]. Total transport accounts for about $19 \%$ of German greenhouse gases and is the third largest emitter after energy conversion (36\%) and industry (21\%). Heavy commercial vehicles-these include tractor-trailers and heavy duty trucks (HDTs) with more than $12 \mathrm{t}$ maximum gross weight-have the highest GHG emissions of all trucks [3]. Most traffic forecasts assume that the transport operations of heavy commercial vehicles will continue to increase (for example [1,4]). Hence, the politically defined ambitious climate targets in Germany, a reduction of at least $55 \%$ of greenhouse gases in 2030 and becoming largely greenhouse gas neutral in 2050, and those worldwide with the Paris agreement, cannot be achieved without heavy commercial vehicles switching to low or zero GHG technologies.

Electric trolley trucks, essentially trucks that can be powered by overhead lines (sometimes also called catenary trucks, catenary hybrid vehicles or electric trucks) are currently in discussion as a solution for reducing the $\mathrm{CO}_{2}$ emissions in the road transport sector. Here, HDTs will be powered by electricity via overhead lines on highly frequented highways and from second energy sources aside from the overhead lines. Generally, hybrid propulsion systems will be implemented which have a pantograph with an electric motor and a conventional combustion engine or a battery that will be charged when connected to the overhead lines. The battery or the combustion engine allow the vehicles to drive on roads without overhead lines or overtaking. This also helps to reduce the infrastructure build-up investments, since critical and expensive highway sections, like bridges or tunnels, can be 
excluded from an infrastructure construction. We will refer to both diesel hybrid trolley trucks and battery hybrid trolley trucks as electric trolley trucks.

Only a limited number of studies exist which focus on overhead line trucks. Most have a focus on a technical description and a first economic evaluation (see [1,5-8]). Research already addressed the different technical questions to realize such a system with two pantographs on the truck: Jerrelind et al. [9] conclude the overhead power system is a viable solution for trucks and buses and Harter et al. [10] presents a radar system that is able to guide the active pantographs. Concerning special applications, as for mining haul trucks [11], such overhead power systems are already in use and beneficial. Additionally, a first demonstration project shows the practical feasibility for heavy-duty freight transport [12].

We study electric trolley trucks from a techno-economic perspective in Germany up to 2030 and analyze their impact on the energy system. We also discuss further fields of research that should be addressed in more detail.

This paper gives an overview of the potentials and challenges for trolley trucks on highways in terms of their technical viability, economic feasibility and energy impacts for heavy commercial vehicles in Germany until 2030. The analysis is conducted for a scenario in which infrastructure is already well developed and used (a so called steady-state situation) and for an earlier phase of a possible market launch. Here, we only compare electric trolley trucks to conventional trucks powered with diesel. Here, we focus on vehicles with a gross vehicle weight of more than $12 \mathrm{t}$. To compare multiple drive trains for the use in trucks, refer to $[13,14]$.

The structure of this paper is as follows. The following section presents the methodology, data and assumptions. Thereafter, results are shown in the three afore-mentioned categories. A discussion of several further fields of research and the conclusion complete this paper.

\section{Methods and Data}

\subsection{Methods}

The market potentials for electric trolley trucks will be analyzed in several steps and the required methods will be introduced in the following. The technical potential will be assessed by identification of the highly used highway sections and which share of heavy-duty transport is operated on them. During a second step, the costs from a user perspective will be calculated followed by the assessment of sales shares based on costs. Finally, the impact on the energy system will be analyzed and compared to the existing local energy demand.

The share of annual vehicle kilometers travelled (VKT) of a truck that is electrified by overhead lines depends on the location and extent of existing overhead line infrastructure. We assume that connected highway segments with the highest heavy-duty traffic will be electrified first. Many times, the distribution of highway traffic is right skewed. Accordingly, it is possible to model the relation between the share of electrified vehicle kilometers and electrified highway kilometers by a Lorenz curve: $\mathrm{y}(x)=1-\Phi\left(\Phi^{-1}(1-x)-\sigma^{2}\right)$ (Here, $y$ denotes the share of electrified vehicle kilometers, $x$ the share of electrified highway kilometers, $\sigma$ is a measure for the skewness of the distribution and $\Phi(x)=1 / 2(1+\operatorname{erf}(x) / \sqrt{ } 2)$ the quantile function of the standard normal distribution and $\Phi^{-1}(x)$ its inverse). We find $\sigma=0.9$ to provide a good fit to the available data and integrate the formula given above into the market potential calculations [15].

The decision about a drive train in heavy-duty vehicles is mainly based on cost $[16,17]$. Most commercial car holders and logistics companies base their decision on per-kilometer cost [3] (See [18] for a discussion of the capabilities and limitations of modelling the purchase decision of vehicles based on costs). Consequently, we compare the total cost of ownership as cost per kilometer for a diesel HDT, battery hybrid and diesel hybrid trolley truck. The total cost of ownership (TCO) contains a cost for the capital expenditure, which is divided by the annual VKT to be comparable to the kilometer-specific cost for the operating expenditure. 
The cost for the kilometer-specific capital expenditure is calculated as follows:

$$
a_{\text {capex }}^{f}=I_{s} \cdot \frac{(1+i)^{\mathrm{T}} i}{(1+i)^{\mathrm{T}}-1} \cdot \frac{1}{\mathrm{VKT}_{f}}
$$

where $I_{s}$ : Investment for vehicle of drive train $s(\mathrm{EUR}) ; i$ interest rate; T: Investment horizon (a); $\mathrm{VKT}_{f}$ : annual vehicle kilometers travelled in vehicle $f$.

The investment for the vehicle $I_{S}$ is discounted to an annuity $a_{\text {capex }}^{f}$ with interest rate $i$ and investment horizon $\mathrm{T}$. Thereafter, it is divided by the annual vehicle kilometers travelled $\mathrm{VKT}_{f}$ in vehicle $f$.

The cost for operating expenditure is calculated as:

$$
a_{\text {opex }}^{f}=\left(s_{e_{f}} \cdot c_{e_{s}} \cdot k_{e}+\left(1-s_{e_{f}}\right) \cdot c_{c_{s}} \cdot k_{c_{s}}\right)+k_{O \& M_{s}}
$$

where $s_{e_{f}}$ : share of driving with primary fuel in vehicle $\left(s_{e_{f}}:=1\right.$ if not a hybrid vehicle); $c_{e_{s}}$ : primary consumption of vehicle with drive train $s(\mathrm{kWh} / \mathrm{km}) ; k_{e}$ : cost for primary fuel (EUR/kWh); $c_{c_{s}}$ : secondary consumption of vehicle with drive train $s$ (only for hybrid vehicles) $(\mathrm{kWh} / \mathrm{km}) ; k_{c_{s}}$ : cost for secondary fuel (only for hybrid vehicles) $(\mathrm{EUR} / \mathrm{kWh}) ; k_{O \& M_{s}}: \operatorname{cost}$ for operations and maintenance for drive train $s(\mathrm{EUR} / \mathrm{km})$.

Thus, for the operating expenditure, we focus on cost for fuel and maintenance $\left(k_{O \& M_{s}}\right)$ and consider variations for hybrid vehicles with two different fuels. Aspects like heavy-duty vehicle toll, insurance, vehicle registration tax and cost for the driver are equal between different drive train technologies today and, for the purpose of this study, no changes until 2030 are included. The annual market share is calculated as the share of vehicles with the lowest-cost drive train of all vehicles. A simple stock model allows us to study the market diffusion (see www.aladin-model.eu for further details).

The impact on the energy system is determined by the increase of electricity demand through electric trolley trucks. We compare this increase to the local energy demand on a NUTS3-level.

\subsection{Data}

Considering the analysis of HDT in Germany, we use the data set "Kraftfahrzeugverkehr in Deutschland 2010" which is a travel survey of about 70,000 vehicles with all vehicle movements on one day of observation [19]. This data set is publicly available and the largest sample of commercial vehicle movements in Germany. Based on the size class information, we can filter for vehicles with an allowed total weight of 40 tons and arrive at $\mathrm{N}=1018$ vehicles for our analysis. We only use two attributes of the sample: the annual vehicle kilometers travelled (VKT) and the VKT on the day of observation, both reported in an accompanying questionnaire to the data collection. The annual VKT distribution is shown in Figure 1. It peaks at 130,000-150,000 km, while there is not such a clear peak for the daily VKT. This implies that vehicles are not used every day, or that the frequency of vehicle usage differs.
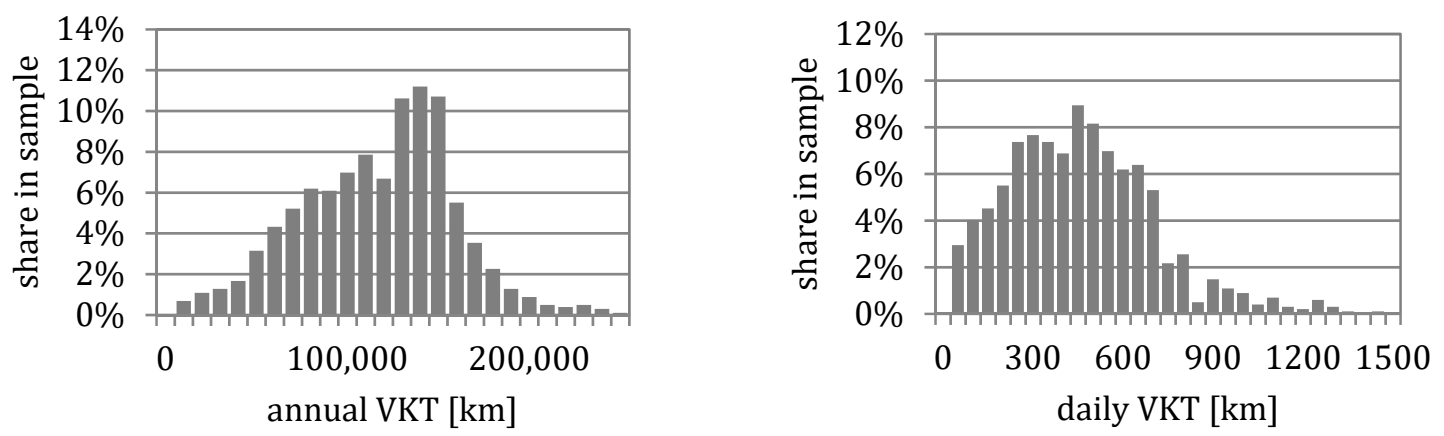

Figure 1. Distribution of annual and daily vehicle kilometers travelled (VKT) [19]. 
To offer the most service to potential truck operators, the overhead line infrastructure should be erected on the most intensively used roads. We combine vehicle count data on the German highway network [20] with information on the length of highway segments [21] to identify parts of the highway network with the highest usage. We match both data sets by the unique combination of highway number and highway section, as determined by the two nearest exits. We thus arrive at a total of 1880 highway sections with the individual length and duty traffic (in thousands of vehicles per day).

\subsection{Techno-Economic Assumptions}

We compare three different drive trains: Diesel vehicles as the benchmark technology; hybrid electric trolley trucks with diesel and with batteries. To compare these drive trains for heavy duty trucks, we need to take a variety of assumptions concerning the vehicles that are listed in Table 1 for Germany in 2030. We list the options' investment, energy consumption, cost for operations and maintenance (O\&M), range if it differs meaningfully from diesel vehicles and specific $\mathrm{CO}_{2}$ emissions. All values are given for 2030 and taken from literature, all prices are given without value added tax in $\mathrm{EUR}_{2016}$.

Table 1. Techno-economic assumptions for comparison [3].

\begin{tabular}{ccccc}
\hline Attribute & Unit & Diesel & Trolley Truck (Diesel) & Trolley Truck (Battery) \\
\hline Investment & $\mathrm{EUR}$ & 128,673 & 152,000 & 189,300 \\
Consumption & $\mathrm{kWh} / \mathrm{km}$ & 2.46 & $2.46 / 1.60$ & 1.60 \\
O\&M & $\mathrm{EUR} / \mathrm{km}$ & 0.143 & 0.135 & 0.107 \\
Range & $\mathrm{km}$ & 2300 & 2300 & 100 (electric) \\
Battery capacity & $\mathrm{kWh}$ & 0 & 0 & 200 \\
$\mathrm{CO}_{2}$ emission $(\mathrm{TtW})$ & $\mathrm{kgCO} / \mathrm{kWh}$ & 0.324 & 0.196 & 0.196 \\
\hline
\end{tabular}

A diesel vehicle in 2030 is assumed to cost about 130,000 EUR while trolley trucks as diesel hybrids have a higher investment due to hybridization and the pantograph which connects to the overhead lines. The battery version has a less costly drive train, but an additional investment for the battery. The consumption for diesel is about $40 \%$ higher compared to trolley trucks when driven in electric mode. The cost for operations and maintenance is based on the cost for diesel vehicles taken from Lastauto Omnibus [22] and adapted using the methodology of Propfe et al. [23] to estimate the lifetimes of different components and their related cost. This leads to a lower O\&M cost for trolley trucks since the conventional drive train with its deteriorating parts is less often used. The trolley trucks with batteries have the lowest O\&M cost, which is dominated by the deterioration of the battery. Ranges differ between the three drive trains since trolley trucks are assumed to have a battery with a range of $100 \mathrm{~km}$. The $\mathrm{CO}_{2}$ emissions are given in $\mathrm{kg} \mathrm{CO}_{2}$ per $\mathrm{kWh}$. All alternative fuel emissions are given as fuels produced from electricity and evaluated with the average emissions of the electricity mix in 2030, explained in the following. Regarding trolley trucks, a loss of $3 \%$ at the medium voltage grid is assumed in 2030.

Furthermore, we have to make assumptions for fuel and battery prices, battery lifetime and $\mathrm{CO}_{2}$ emissions of the German power sector in 2030, which are shown in Table 2.

Table 2. General assumptions for comparison based on Wietschel et al. [3].

\begin{tabular}{ccc}
\hline Parameters (All Prices w/o VAT in EUR 2016) & Unit & Value 2030 \\
\hline Battery price & EUR/kWh & 186 \\
Battery life-time & Full cycles & 5000 \\
Diesel price & $\mathrm{EUR} / \mathrm{l}$ & 1.53 \\
Diesel price & $\mathrm{EUR} / \mathrm{kWh}$ & 0.15 \\
Electricity price, industrial & $\mathrm{EUR} / \mathrm{kWh}$ & 0.16 \\
Average $\mathrm{CO}_{2}$ emissions of German power plants & $\mathrm{t} \mathrm{CO} / \mathrm{MWh}$ & 0.192 \\
\hline
\end{tabular}


The battery lifetime determines the number of full cycles after which a battery has to be replaced. This is an important aspect for the O\&M cost of trolley trucks with batteries. We assume 5000 full cycles to be the lower bound until 2030. Regarding fuel and natural gas prices, the current reduction of energy taxes for natural gas is neglected. The average $\mathrm{CO}_{2}$ emissions stem from a simulation of the electricity mix in 2030 based on the Climate Protection Scenario for 95\% GHG reduction scenario in Repenning et al. [24], which aims at reaching the $95 \% \mathrm{CO}_{2}$ reduction until 2050 compared to 1990, and the share of renewable energies on the electricity production is $50 \%$.

\section{Results and Discussion}

The present section contains the results on the technical and market assessment (Section 3.1), the overall economic assessment (Section 3.2) and the effect on the energy system and GHG emissions (Section 3.3).

\subsection{Technical Assessment and Market Introduction}

The first group of results concerns the technical potentials of electric trolley trucks. These can only drive directly with electricity if they are connected to the overhead cable. Thus, the first step is to estimate the share of kilometers driven on highways with overhead lines. Since we do not have geographical information about the driving of the vehicles, we make two simplifications. First, we use a non-linear fit for the share of kilometers on a highway $s_{h}$ based on WVI et al. [19]. Here, survey participants stated which share of their daily vehicle kilometers travelled $(d V K T)$ were driven on highways and we analyzed the average share with respect to the total daily VKT. We obtain $s_{h}=1-\exp \left(-\frac{d V K T}{L_{0}}\right)$ with $L_{0}=127.3 \mathrm{~km}$ from a least squares regression of the survey data. We thus obtain the share of $\mathrm{km}$ driven on highways. Concerning the second step, the share of driving on a highway that is equipped with catenaries, we assume that the highly utilized highways are equipped with overhead lines first. We order the highway segments by the number of truck-km per segment within a highway and, thus, obtain stretches with very high average utilization. Figure 2 shows the resulting share of mileage $\left(s_{m}\right)$ of heavy duty vehicles over the share of highway kilometers ordered by their usage, based on Wietschel et al. [3]. Thus, if the most frequented $20 \%$ of highways had overhead lines, almost $50 \%$ of the mileage of heavy duty vehicles would be electrified. The product of the share, if driving on a highway $s_{h}$ and of driving on a highway with catenaries $s_{m}$, results in the overall share of kilometers driven electrically $\left(s_{e}\right)$.

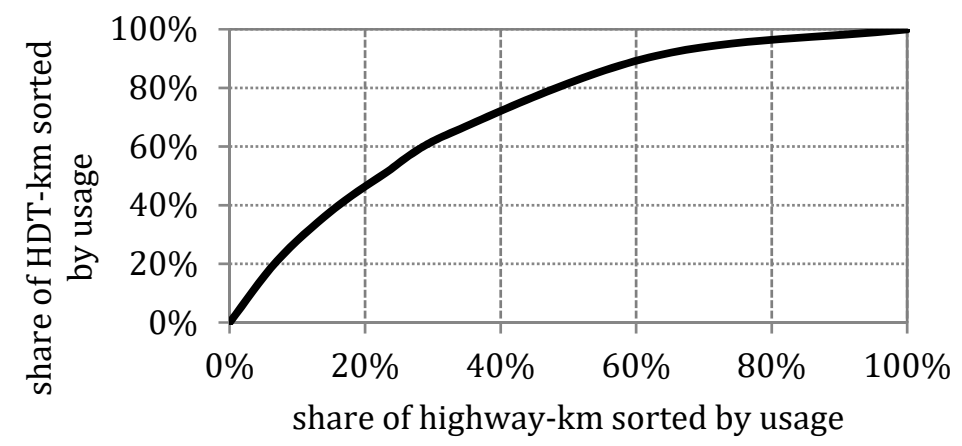

Figure 2. Share of mileage of heavy-duty trucks (HDT) over share of most frequented highway kilometers.

\subsection{Economic Assessment and Market Potential}

Presently, electric trolley trucks are still in the market preparation phase. Alternative vehicle and power supply technologies are being developed and presented in demonstrators. The first pilot projects on public motorway test tracks are planned or under construction. The first small series production of trolley trucks probably only will start in two to three years at the earliest. Under optimistic assumptions, the market can start to take off in Germany by 2025. 
Generally speaking, the economic efficiency of heavy trucks is dominated by their running costs due to the high vehicle kilometers of around 130,000 km per year in long distance haulage. Diesel purchase accounts for around 30\% of truck operating costs in Germany (cf. Figure 3 where $0 \mathrm{~km}$ annual VKT show the annual capital expenditure and everything above a fictive horizontal line stems from distance dependent operating expenditure). Thus, fuel expenses and fuel economy are therefore decisive. The trolley truck is often superior to other alternatives due to its efficiency.

Here, the economic evaluation of trolley trucks is based on TCO analyses for the individual annual VKT (cf. methods section). The first major economic result is that overhead line trucks with a diesel engine as a hybrid component can be an economically viable solution for a large fraction of HDTs. However, this does not include the costs for constructing the overhead power lines and assumes the lines are used to capacity. Other studies come to a comparable result in this respect $[6,7,25,26]$. The TCO for trolley trucks, however, depend on the amount of overhead line infrastructure. We show the TCO for diesel vehicles as well as diesel trolley trucks with three different amounts of overhead line infrastructure in Figure 3.

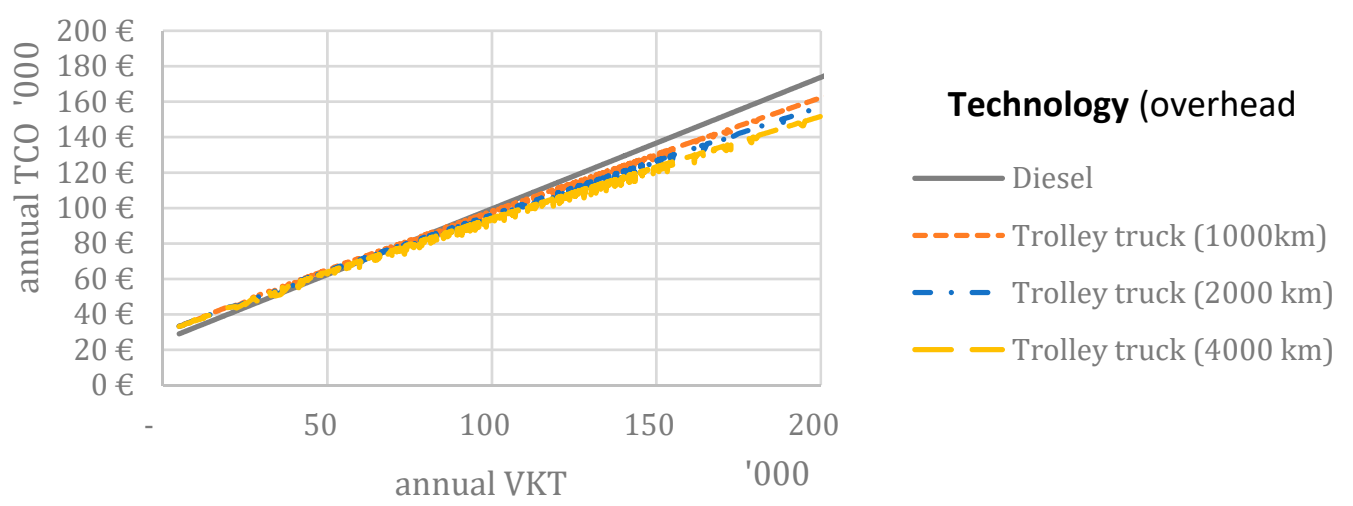

Figure 3. Total cost of ownership (TCO) over annual vehicle kilometers traveled (VKT) for different drive trains.

We find a relatively low TCO intersection for diesel and trolley trucks which ranges between 30,000 and $70,000 \mathrm{~km}$ depending on the extension of overhead lines. This reveals from the fact that a comparatively low number of electrical vehicle kilometers on the overhead line per trolley truck, from 20,000 to $30,000 \mathrm{~km} /$ year, is sufficient to amortize the additional costs of converting a conventional diesel truck to an electric trolley truck with a diesel motor. As part of the hybrid propulsion system, the diesel engine guarantees the flexibility of use of the trolley truck when it is driven alongside electrified roads. Economic efficiency calculations also are made for the trolley truck variant using a battery rather than an internal combustion engine but revealed that the option is not yet economically viable in the short- and medium-term, under the assumptions made.

Assuming an infrastructure of $4000 \mathrm{~km}$ in 2030, we find approximately $25 \%$ of the heavy-duty vehicle stock (approximately 50,000-70,000 trucks) could be trolley trucks by 2030. Yet, the time needed to construct infrastructure, develop and build trolley trucks and replace existing trucks should not be underestimated. The cost for the catenary infrastructure has been assumed to be $2.2 \mathrm{~m} \mathrm{EUR/} / \mathrm{km}[3]$. Investments in the overhead line infrastructure would thus amount to approximately 8-10 billion euros for this case. The question is whether this overhead line infrastructure can create enough savings to cover its own cost. We show the annual cost for additional overhead cable infrastructure and the savings from the usage of trolley trucks in relation to the length of the overhead lines infrastructure in Figure 4 in 2030. 


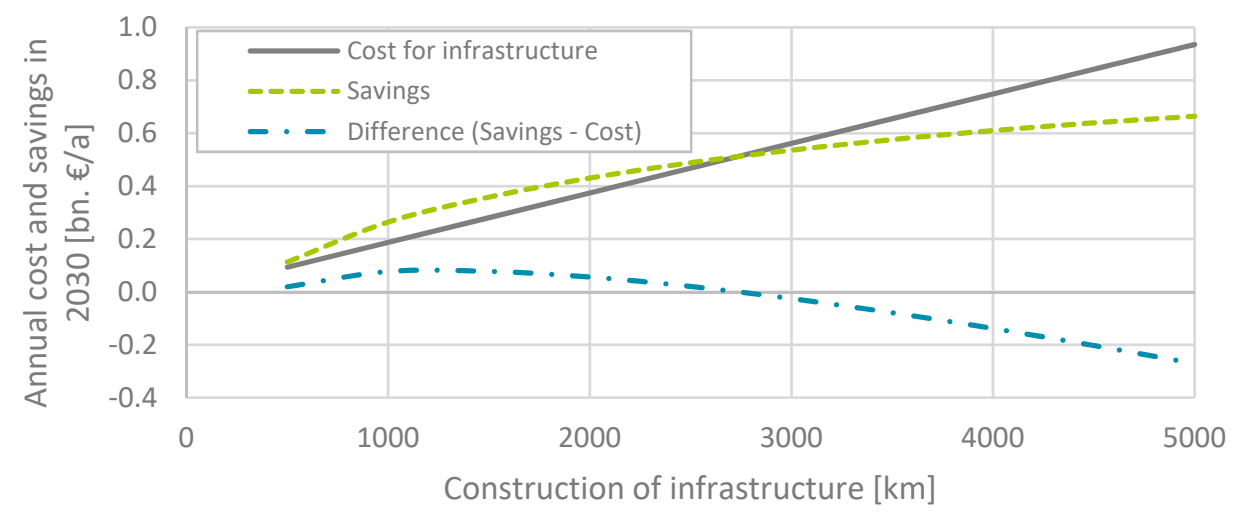

Figure 4. Annual cost for overhead line infrastructure and fuel cost savings through trolley trucks in 2030.

The annual costs for infrastructure are calculated as an annuity with 30 years of utilization, a $5 \%$ interest rate, no residual value plus $2 \%$ of the investment for operations and maintenance [3]. The savings are calculated individually for every vehicle that is switched to trolley trucks. We find a positive effect of additional charging infrastructure until about $2500 \mathrm{~km}$ of overhead lines is constructed, while the cost for more infrastructure exceeds the savings. This is a consequence of the reduced marginal effect of electrification of less frequented highway sections.

\subsection{Greenhouse Gas Balance and Impacts on Energy Systems}

When operating electrically, trolley trucks are twice as energy efficient (well-to-wheel, WtW) as conventional diesel-powered HDTs (70-75\% compared to 30-35\%). Other solutions based on electricity, such as hydrogen, renewable methane or renewable methanol, also have lower efficiencies when used to operate vehicles. Analyzing total efficiency from well to wheel, then hydrogen and, especially, renewable methane or methanol, have much lower efficiencies than trolley trucks. Therefore, the additional renewable generation capacities required to cover the electricity demand of trucks are much lower for introducing trolley trucks than for other electricity-based fuels derived from renewable energy sources (about double for hydrogen and triple for methane from renewables $[13,14])$. This can be an important argument in terms of a comprehensive climate protection strategy in Germany in which electricity-based renewable fuels play an important role.

Taking an energy management viewpoint, trolley trucks may mean a considerable increase in power demand (by approximately $+1.6 \%$ (ca. $+8 \mathrm{TWh} / \mathrm{a}$ ) for 60,000 trucks). Demand varies widely by region and the load, and demand can increase by up to $30 \%$ in certain rural regions with an overhead line motorway. Large additional loads are expected, especially at very busy motorway intersections in rural areas., The regions of Helmstedt, Soltau-Fallingbostel, Hersfeld-Rotenburg, Heilbronn, and Kitzingen, for example, show an increase in electricity demand between 20 and $30 \%$ in a scenario with $4000 \mathrm{~km}$ (approximately 30\% of the German highway network) of overhead line installation. They are all rural with one or more highways crossing them. However, because the deployment of renewables often also takes place in rural regions, there may well be positive effects for the system integration of renewables.

A challenge in terms of energy management is that heavy trucks represent a largely inflexible demand, and, in addition, this demand occurs more during the day and on weekdays. This significantly increases the peak load on weekdays (+2 GW in 2030 with 60,000 trolley trucks). This results in new flexibility having to be made available at other points of the energy system, for example via electricity storage, grid expansion or load management.

Viewing a local level, electric trolley trucks lead to an increase of electricity demand during driving hours in areas around the electrified highways. Figure 5 shows the change of local annual electricity demand on the NUTS-3 level in Germany, with respect to a reference evolution. The left panel shows 
the relative change in a market scenario with $1000 \mathrm{~km}$ of overhead lines, the right panel for $4000 \mathrm{~km}$. We find only slight increases on the local energy demand in the $1000 \mathrm{~km}$ case, while there are a few more regions with a $20-50 \%$ raise in energy demand for $4000 \mathrm{~km}$. These especially occur in rural areas with high highway usage, especially at highway junctions. Overall, the impact on the energy system is lower than for other new technologies and seems manageable.

An holistic analysis of $\mathrm{CO}_{2}$ e emissions using a life cycle assessment approach (which also integrates the production of trolley trucks and the development of overhead line infrastructure) reveals that the $\mathrm{CO}_{2} \mathrm{e}$ emission balance is clearly dominated by the vehicle utilization phase [3]. When the average GHG emissions of the electricity mix in 2030 are applied [24], then trolley truck production and infrastructure development only account for about $3 \%$ of the $\mathrm{CO}_{2} \mathrm{e}$ emissions. This applies when considering the diesel trolley truck variant. When a large battery is assumed as a hybrid solution, then there is a clear rise in $\mathrm{CO}_{2} \mathrm{e}$-relevant emissions during vehicle production, yet they still play only a subordinate role in terms of the overall assessment. Here, a relevant difference to a life cycle analysis of passenger vehicles (see [27]) can be observed. Regarding passenger vehicles, the vehicle production phase has a relevant impact on the $\mathrm{CO}_{2}$ emission balance.

Assuming maximal stock share $(250,000$ electric trolley trucks in the vehicle stock in the long run), the introduction of trolley trucks could save 10-12 million tons of greenhouse gas emissions compared to conventional diesel trucks if the electricity used to power them is supplied exclusively from renewable energy sources. The average electrical driving share then amounts to $60 \%$ with overhead power lines deployed along $4000 \mathrm{~km}$ of motorway. This also implies, however, that, under ambitious climate targets, the remaining $40 \%$ also would have to be generated with zero $\mathrm{CO}_{2}$ in the long term. This may, for example, be done using hybrid solutions based on methanol, using renewable energy sources, fuel cells or batteries.
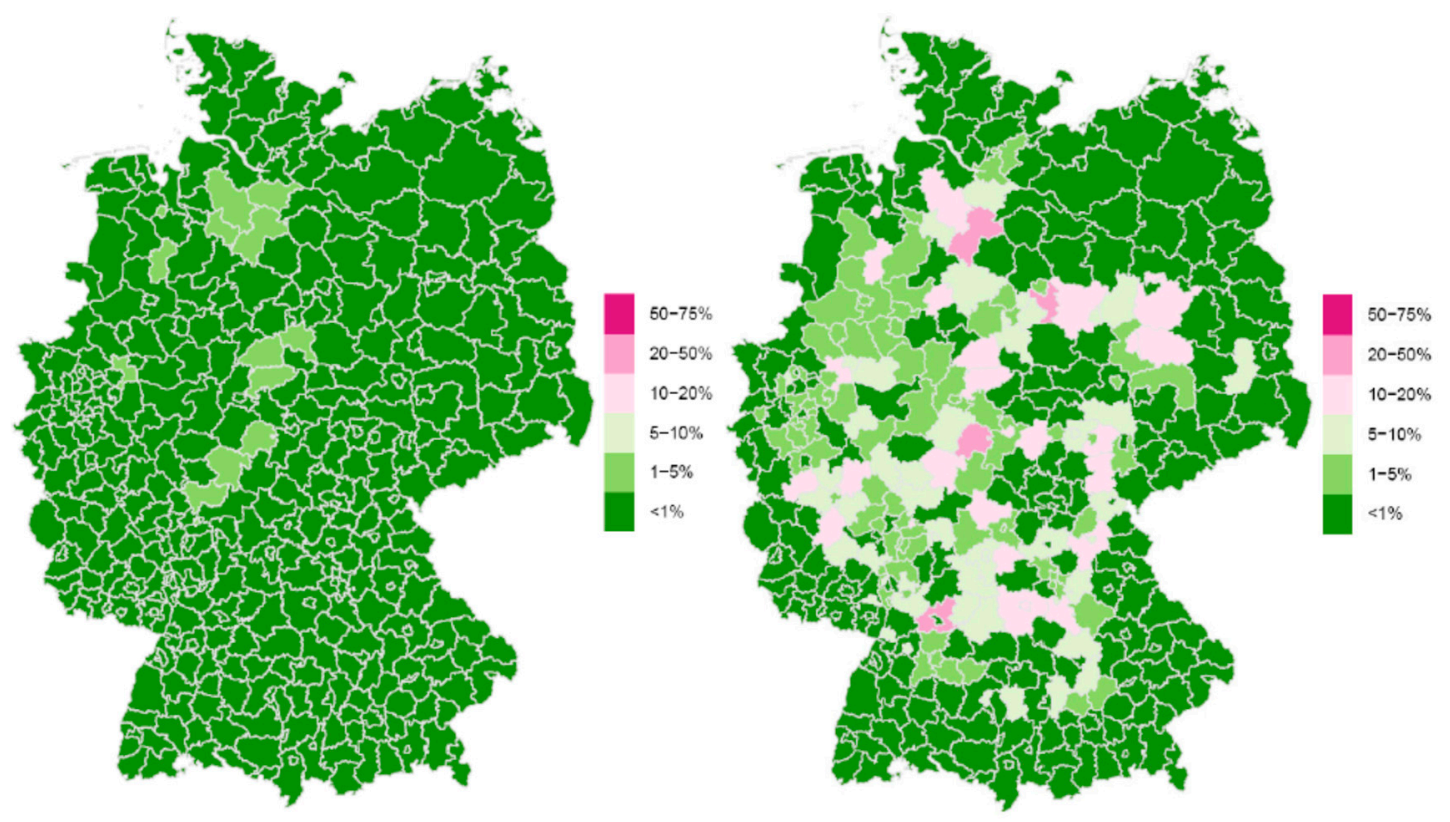

Figure 5. Change in local electricity demand in 2030 due to trolley trucks. Left: Market diffusion with $1000 \mathrm{~km}$ of overhead lines. Right: $4000 \mathrm{~km}$.

\section{Discussion and Aspects Neglected}

\subsection{Discussion of Methodology and Assumptions}

The aim of this paper was to show the technical and economical market potentials and impact on the energy system. We therefore analyzed several data sets to understand the technical feasibility and used a TCO model to determine market shares in the following. Certainly, methods, data and further 
assumptions can be questioned in this case. Analyzing data from large data sets seems to be a good approximation for the driving behavior of a fleet and has been performed in several studies. This also seems reasonable as a method for economical comparison, since modest decisions from commercial vehicle fleet owners are based on cost $[16,17]$. All assumptions for calculations have been discussed in Section 2.3 while more details can be found in [3].

Furthermore, the results are discussible in light of assumptions made. Several aspects of the market diffusion have been tested with sensitivity analyses. Yet, the market shares for trolley trucks with diesel did not show large impacts on energy prices (price for diesel and electricity) and interest rates, as they also can be driven in conventional mode and only some driving below the overhead line is enough (cf. [3] for details). A large influence was visible in the amount of infrastructure available, which was discussed in Section 3.

\subsection{Further Research}

Apart from that, there are several aspects that could have a large impact on results and should thus be mentioned: (1) Who will finance infrastructure? (2) Is there political, market and user acceptance? (3) What about other technical options? (4) Is rail freight not much more energy and cost efficient? These are briefly discussed in the next subsections.

\subsubsection{Infrastructure Financing}

Our results indicate that users cannot bear the infrastructure cost in the market development phase, but in a steady state [27]. Therefore, the question has to be asked, how the infrastructure can be pre-financed. Various scenarios are possible depending on the political priorities, legal basis and the question of whether the initiative comes from the state or the private sector. Assuming the state itself is the initiator, it has the option of financing it either from the budget (i.e., via tax revenues) or via user fees. Given the annual investment deficit accounted for in the transport sector and the German constitution's balanced budget amendment (sometimes referred to as a "debt brake"), it does not seem very realistic to finance the infrastructure using tax revenue from the budget. Financing via user fees is more likely, and private capital can be integrated here for pre-financing via public-private partnerships (PPP). Such PPPs are particularly concerned with spreading risk and, therefore, with contractual arrangements. To design a specific PPP, an in-depth analysis is required of possible stakeholders, such as network operators, technology providers and banks offering loans and financing services.

Ultimately, relevant delays in the market introduction and rollout of trolley trucks could result in the set climate policy targets not being able to be achieved and, therefore, other paths of GHG reduction having to be taken for heavy-duty trucks. This means that policy-makers should make the decision for or against the further development of trolley trucks in the near future. Then, the political framework conditions have to be set for heavy trucks, such as GHG reduction targets and GHG reduction regulations. Concerning the medium term, a European solution should be targeted, because a purely German one is hardly realizable for cost reasons.

\subsubsection{Gradual Market Diffusion}

We showed that trolley trucks can be cost-effective for users, even if the infrastructure costs are paid by the users. However, the question remains of how to reach certain market shares over time. Several pathways to wider market diffusion seem plausible. One pathway would start to electrify the most important national highways and gradually expand the overhead line network, for example in steps of $5 \%, 10 \%$, and up to $35 \%$ of the highway network. Such a network could grow in different directions with interconnected parts of the highway network. Market diffusion of trucks would follow. Alternatively, isolated islands within the highway networks could first be electrified. These islands would electrify local traffic between two logistics or economic centers. After some time, the islands would increase by including larger parts of the highway network. The stock of trolley trucks also would follow the growth of the network with some delay, according to stock turnover time scales. 
However, even in a well-developed stage of market diffusion, the network equipped with overhead lines does not need to be a closed network.

Important aspects in long-term market diffusion are international standards and a cross-national development of the grid, as heavy-duty traffic is often cross-national. Such a network also could be combined with high-powered fast-charging stations for electric heavy-duty trucks such that a co-existence of both infrastructures seems feasible. Further research could analyze both the market diffusion dynamics and its impacting factors, as well as the mutual effect of both electric charging infrastructures.

\subsubsection{Market and User Acceptance}

Alongside pre-financing and the time required for developing infrastructure, acceptance for this technology by policy-makers, logistics providers and the public represents a major challenge for trolley trucks.

Analyses of the European Commission's current transport policy have shown that political acceptance is limited, due to the competition with railways. Furthermore, the concept is of less importance in other large European countries that are relevant for trucks. Yet, it would be advantageous to expand the trolley truck network to Germany's neighboring countries. This also would make sense from the viewpoint of the EU's climate policy objectives. However, in transport policy terms, this expansion would be contrary to the EU's goal of shifting freight traffic from the roads to rail, especially for long-distance and cross-border transport (cp. [28]).

There also appears to be little acceptance among logistics providers and haulage companies. Since high shares of vehicle kilometers driven using the overhead lines increases efficiency, there is less flexibility when using trolley trucks aside from electrified routes. Flexibility is, however, the particular strength of truck-based logistics. Additionally, costs are extremely important for logistics companies due to the current strong competition with foreign suppliers and their lower labor costs. The trolley truck could score well here with logistics service providers in Germany.

Currently, there are still many unresolved questions concerning local acceptance. It has not yet been explored whether people living near motorways would feel more disturbed by the additional overhead lines, or whether the local reduction of emissions, noise, particulates and $\mathrm{NO}_{\mathrm{x}}$ would be accorded more weight. Nor have there been sufficient scientific studies of whether motorway users perceive overhead lines as restricting visibility or of how truck drivers evaluate trolley truck performance, for example faster acceleration and less noise inside the cab. The German pilot projects should therefore be used for a comprehensive analysis of local acceptance issues.

Generally, more detailed analysis of acceptance issues is required because they represent a very relevant barrier for a diffusion of trolley trucks.

\subsubsection{Alternative Technical Options}

To contrast to the overhead line concept, conductive charging systems through conductors in the road surface and inductive charging systems using induction loops under the road surface also are being discussed as alternative ways of supplying power. Configurations of the different variants and cost estimates show that both systems are significantly more expensive than the overhead line variant. The cost advantage of the overhead line system compared to the conductive charging system using power rails equals around 33-80\%, depending on the variant considered; the costs for the road-side infrastructure of the inductive charging system are more than $100 \%$ higher than the costs for the overhead line infrastructure in all variants. Additionally, they lead to higher vehicle purchasing prices and the inductive systems have higher power consumption due to their lower efficiency.

There is the need for more research on the alternative power supply solutions concerning the possibilities of passenger cars using the charging infrastructure and the resulting technical, business and economic consequences. Additionally, analyses are needed to assess the alternative charging 
systems with regard to the resulting traffic restrictions and disruptions, the installation of road-side infrastructure and its traffic safety.

\subsubsection{Comparison to Rail Freight}

A major concern with catenary hybrid trucks is their competition with the railways. Regarding the German rail network, around $90 \%$ of freight train kilometers are performed by electric traction. Therefore, GHG emissions per ton kilometer by rail are a third of emissions with trucking [29] and railways will profit as well from the decarbonization of the power sector. Model calculations prior to first field tests of longer and heavier trucks (LHVs) in Germany have shown some rail markets react very sensitively to one-sided cost advantages in the road sector. This is primarily the case for single wagon load (SWL) and combined road-rail transport (CT) services. Both are capital intensive and involve costly train formation and cargo handling procedures. Concerning $\mathrm{CT}$, which was built up with considerable European and national subsidy programs, money is still earned with the last few containers on a train.

Regarding the urgency of driving down the freight sector's GHG emissions, a double strategy needs to be followed. First, all options for decarbonizing the road sector need to be exploited. Besides catenary trucks, this might be longer and heavier vehicles, synthetic and electricity-based combustion fuels and commonly accepted platforms for selling otherwise unused load space on trucks. Concurrently, the effort of improving the railways' market position and competitiveness need to continue. The EU's freight corridor concept is a good basis for modernizing the most relevant rail markets through international coordination. However, market needs and customer requirements need to guide developments which are now mainly managed with a sector-internal optimization focus.

Current policies for modernizing and strengthening the railway sectors in some European countries show some sign of success. Investment initiatives are pushed forward at EU and national levels, as it seems unlikely to achieve $\mathrm{CO}_{2}$ targets without a considerable modal shift [30]. Considering the analysis of European freight corridors, Woodburn et al. [31] give an overview of several modelling techniques for analyzing mode shift risks and potentials in the freight sector. Measures to get-or keep—goods off the road include taxation, financial aids for investments or operations, regulations in form of licensing or standards and, of course, infrastructure provision [32,33]. Most sources conclude that, on the local level such as along a particular trolley truck route, specific measures with regard to goods types and quantities, origin-destination-pairs, etc. are needed to prevent unwanted mode shifts

\section{Summary and Conclusions}

The above analyses lead to the following conclusions. Regarding a mass market with sufficient infrastructure, overhead line trucks could be economical, even with low electric driving shares. They could reduce significantly the GHG emissions of the transport sector (10-12 $\mathrm{Mt} \mathrm{CO}_{2} \mathrm{e}$ in 2030) if the electricity will come from renewables or other GHG-free sources. Only a limited number of highways $(\sim 30 \%)$ need to be equipped with trolley systems due to the high concentration of trucks on certain highways, which lead to limited infrastructure investments.

However, a lot of serious barriers for the introduction exist. The infrastructure has to be pre-financed and the state has to play an active role. Acceptance is critical from different points of view. German and European policy-makers, truck producers, as well as trolley truck users, have to be convinced and local acceptance is an open question. Alternatives like hydrogen trucks, synthetic fuels or liquefied natural gas could be concurrent options, yet they also have barriers to overcome (see e.g., [14]).

Serious policy action is desired and should be started in time due to the necessary time to market if trolley trucks should be implemented.

Author Contributions: Conceptualization, M.W., P.P. and T.G.; methodology, M.W., T.G.; software, T.G.; validation, M.W., T.G. and P.P.; formal analysis, P.P., T.G.; data curation, T.G.; writing: M.W., P.P., T.G., C.D.

Funding: Parts of this research were carried out in the Scientific Advisory for the German Mobility and Fuels Strategy of the Federal Republic of Germany carried out by the Federal Ministry of Transport and Digital 
Infrastructure (Contract Number G20-3552.1/1). This publication was written in the framework of the Profilregion Mobilitätssysteme Karlsruhe, which is funded by the Ministry of Economic Affairs, Labour and Housing in Baden-Württemberg and as a national High Performance Center by the Fraunhofer-Gesellschaft.

Conflicts of Interest: The authors declare no conflict of interest.

\section{References}

1. International Energy Agency (IEA). The Future of Trucks-Implications for Energy and the Environment; OECD/IEA: Paris, France, 2017.

2. Blanck, R.; Kasten, P.; Hacker, F.; Mottschall, M. Treibhausgasneutraler Verkehr 2050: Ein Szenario zur zunehmenden Elektrifizie-rung und dem Einsatz stromerzeugter Kraftstoffe im Verkehr. Abschlussbericht im Auftrag des Umweltbundesamtes zum Forschungsvorhaben. In Verkehr 2050—Entwicklung von Pa-rametern und Skizzierung eines vereinfachten Energie und Emissionsszenarios; Öko-Institute.V.: Berlin, Germany, 2013.

3. Wietschel, M.; Gnann, T.; Kühn, A.; Plötz, P.; Moll, C.; Speth, D.; Stütz, S.; Schellert, M.; Rüdiger, D.; Balz, W.; et al. Machbarkeitsstudie zur Ermittlung der Potentiale des Hybrid-Oberleitungs-Lkw. In Studie im Rahmen der wissenschaftlichen Beratung des BMVI zur Mobilitäts-und Kraftstoffstrategie; Bundesregierung, Fraunhofer ISI, Karlsruhe, Fraunhofer IML, Dortmund, PTV Transport Consult GmbH, Stuttgart, Karlsruhe, TU Hamburg-Harburg, Hamburg, M-Five: Karlsruhe, Germany, 2017.

4. European Union (EU). 1. EU Reference Scenario 2016-EU and EU Country Results. 2017. Available online: https://data.europa.eu/euodp/de/data/dataset/energy-modelling/resource/9c3eaead-81b8-4a3d-a23d4dd4a13f3c6e (accessed on 3 August 2017).

5. Grontmij. Elektriska vägar-Elektrifiering av tunga vägtransporter; Förstudie; Grontmiij: Stockholm, Sweden, 2010.

6. SRU. Umweltgutachten 2012 - Verantwortung in einer begrenzten Welt; Sachverständigenrat für Umweltfragen, Erich Schmidt Verlag: Berlin, Germany, 2012.

7. den Boer, E.; Aarnik, S.; Kleiner, F.; Pagenkopf, J. Zero Emissions Trucks, An Overview of State-of-the-Art Technologies and Their Potential; CE Delft: Delft, The Netherlands; German Aerospace Center: Stuttgart, Germany, 2013.

8. Hey, C. Postfossil Freight Transport-Assessment of Strategy Capproaches: Truck $\mathrm{CO}_{2}$-Time to Turn up the Voltage? Potential and Challenges for Electric Road Freight, European Parliament. Presented at German Advisory Council on the Environment (SRU), Berlin, Germany, 16 February 2016.

9. Jerrelind, J.; Drugge, L.; Stensson Trigell, A.; Nybacka, M. Simulation of Vehicle-Overhead Power System Interaction on Electric Roads. In Proceedings of the 13th MINI Conference on Vehicle System Dynamics, Identification and Anomalies, Budapest, Hungary, 5-7 November 2012.

10. Harter, M.; Schipper, T.; Zwirello, L.; Ziroff, A.; Zwick, T. Detection of Overhead Contact Lines with a 2D-Digital-Beamforming Radar System for Automatic Guidance of Trolley Trucks. Int. J. Veh. Technol. 2013, 2013, 914351. [CrossRef]

11. Mazumdar, J. Performance improvement of mining haul trucks operating on trolley systems. In Proceedings of the Industry Applications Society Annual Meeting (IAS), Orlando, FL, USA, 9-13 October 2011. [CrossRef]

12. Akerman, P.; Gruenjes, H.G.; Lehmann, M. Designing and Demonstrating an Electric Road System for Efficient and Sustainable Road Freight. In Proceedings of the Transportation Research Board 96th Annual Meeting, Washington, DC, USA, 8-12 January 2017.

13. Gnann, T.; Kühn, A.; Plötz, P.; Wietschel, M. How to Decarbonise Heavy Road Transport? In ECEEE Summer Study Proceedings; European Council for an Energy-Efficient Economy: Paris, France, 2017; pp. 901-909.

14. Gnann, T.; Plötz, P.; Wietschel, M.; Kühn, A. What is the best alternative drive train for heavy road transport? Presented at the EVS30, International Battery, Hybrid and Fuel Cell Electric Vehicle Symposium \& Exhibition, Stuttgart, Germany, 9-11 October 2017.

15. Plötz, P.; Gnann, T.; Jochem, P.; Yilmaz, H.Ü.; Kaschub, T. Impact of electric trucks powered by overhead lines on the European electricity system and $\mathrm{CO}_{2}$ emissions. Energy Policy 2019, 130, 32-40. [CrossRef]

16. Globisch, J.; Dütschke, E. Anwendersicht auf Elektromobilität in gewerblichen Flotten. In Ergebnisse aus den Projekten mit gewerblichen Nutzern von Elektrofahrzeugen im Rahmen des BMVBS-Vorhabens "Modellregionen für Elektromobilität 2009-2011"; Fraunhofer ISI: Karlsruhe, Germany, 2013. 
17. Sierzchula, W. Factors influencing fleet manager adoption of electric vehicles. Transp. Res. Part D Transp. Environ. 2014, 31, 126-134. [CrossRef]

18. Plötz, P.; Gnann, T.; Wietschel, M. Modelling market diffusion of electric vehicles with real world driving data-Part I: Model structure and validation. Ecol. Econ. 2014, 107, 411-421. [CrossRef]

19. WVI; IVT; DLR; KBA. Kraftfahrzeugverkehr in Deutschland 2010 (KiD2010); WVI Prof. Dr.Wermuth Verkehrsforschung und Infrastrukturplanung GmbH: Braunschweig, Germany; IVT Institut für angewandte Verkehrs-und Tourismusforschung e. V.: Heilbronn, Germany; DLR Deutsches Zentrum für Luft-und Raumfahrt-Institut für Verkehrsforschung: Berlin, Germany; KBA Kraftfahrt-Bundesamt: Flensburg, Germany, 2010.

20. BASt (Bundesanstalt für Straßenwesen). Manuelle Straßenverkehrszählung 2010—Ergebnisse auf Bundesautobahnen. 2010. Available online: http://www.bast.de/DE/Verkehrstechnik/Fachthemen/v2verkehrszaehlung/zaehl_node.html (accessed on 5 May 2019).

21. BASt (Bundesanstalt für Straßenwesen). Mauttabelle 2016. Herausgegeben von der Bundesanstalt für Straßenwesen. Available online: http://www.mauttabelle.de/maut_162.html (accessed on 13 March 2017).

22. Lastauto Omnibus. Lastauto Omnibus-Katalog, 1st ed.; Motorbuch: Stuttgart, Germany, 2014.

23. Propfe, B.; Redelbach, M.; Santini, D.J.; Friedrich, H. Cost Analysis of Plug-in Hybrid Electric Vehicles including Maintenance E Repair Costs and Resale Values; German Aerospace Center: Stuttgart, Germany; Argonne National Laboratory, Transportation Technology R\&D Center (Argonne): Los Angeles, CA, USA, 2012.

24. Repenning, J.; Emele, L.; Blanck, R.; Böttcher, H.; Dehoust, G.; Förster, H.; Braungardt, S.; Eichhammer, W.; Elsland, R. Klimaschutzszenario 2050-2. Endbericht. In Studie im Auftrag des Bundesministeriums für Umwelt, Naturschutz, Bau und Reaktorsicherheit; Öko-Institut e.V., Fraunhofer ISI: Berlin, Germany, 2015.

25. Kasten, P.; Mott-schall, M.; Köppel, W.; Degünther, C.; Schmied, M.; Wüthrich, P. Erarbeitung einer fachlichen Strategie zur Energieversorgung des Verkehrs bis zum Jahr 2050. In Studie im Auftrag des Umweltbundesamtes; Öko-Institut e.V., DVGW-Forschungsstelle am Engler-Bunte-Institut des Karlsruher Instituts für Technologie (KIT), INFRAS: Berlin, Germany, 2016.

26. UBA. Klimaschutzbeitrag des Verkehrs bis 2050. Studie für das Bundesministerium für Umwelt, Naturschutz, Bau und Reaktorsicherheit; Durchgeführt von ifeu, INFRAS AG und LBST: Berlin, Germany, 2016.

27. Plötz, P.; Funke, S.A.; Jochem, P.; Wietschel, M. $\mathrm{CO}_{2}$ Mitigation Potential of Plug-in Hybrid Electric Vehicles larger than expected. Sci. Rep. 2017, 7, 16493. [CrossRef] [PubMed]

28. Yeh, S. An empirical analysis on the adoption of alternative fuel vehicles: The case of natural gas vehicles. Energy Policy 2007, 35, 5865-5875. [CrossRef]

29. European Commission. White Paper Roadmap to a Single European Transport Area-Towards a Competitive and Resource Efficient Transport System; COM/2011/0144; European Commission: Brussels, Belgium, 2011.

30. McKinnin, A. The Role of Government in Promoting Green Logistics. In Green Logistics-Improving the Environmental Sustainability of Logistics; McKinnon, A., Cullinane, S., Browne, M., Whiteing, A., Eds.; MPG Books Ltd.: Cornwall, UK, 2010; Chapter 17; pp. 341-360.

31. Woodburn, A.; Whiteing, A. Transferring Goods to 'Greener' Modes. In Green Logistics_Improving the Environmental Sustainability of Logistics; McKinnon, A., Cullinane, S., Browne, M., Whiteing, A., Eds.; MPG Books Ltd.: Cornwall, UK, 2010; Chapter 6; pp. 124-139.

32. van Hassel, E.; Vanelslander, T.; Doll, C. The Assessment of Different Future Freight Transport Scenarios for Europe and the North Rhine-Westphalia Region; Working Paper 7 to the Study LowCarb RFC-European Rail Freight Corridors Going Carbon Neutral, supported by Stiftung Mercator (Essen); University of Antwerp, Fraunhofer ISI: Karlsruhe, Germany, 2018.

33. Doll, C.; Köhler, J.; Schade, W.; Mader, S.; van Hassel, E.; Vanelslander, T.; Sieber, N. European Freight Scenarios and Impacts; Summary Report 2 to the Study LowCarb RFC—European Rail Freight Corridors Going Carbon Neutral, supported by Stiftung Mercator (Essen); Fraunhofer ISI: Karlsruhe, Germany, 2018.

(C) 2019 by the authors. Licensee MDPI, Basel, Switzerland. This article is an open access article distributed under the terms and conditions of the Creative Commons Attribution (CC BY) license (http://creativecommons.org/licenses/by/4.0/). 